\title{
NE ESIS
}

Negative Effects in Medical Sciences Oral and Maxillofacial Surgery

Cone beam computed tomography in the diagnosis of Stafne bone cavity: Report of seven cases and review of the open-access literature.

\author{
Authors: \\ Dive $B$ MD, DDS \\ Aps J DDS, MSc, MSc, PhD, Prof', \\ Hulyev D, DDS ${ }^{3}$, \\ Gurniak A, DDS ${ }^{4}$, \\ Klein-Dębek E, DDS, PhD ${ }^{5}$, \\ Beyls H, DDS 6 , \\ Hebda A, MS ${ }^{7}$, \\ Olszewski R DDS, MD, PhD, DrSc, Prof $17,7^{\prime}$
}

Affiliations:

${ }^{1}$ Department of Oral and maxillofacial surgery, Cliniques universitaires saint Luc, UCLouvain, Brussels, Belgium

${ }^{2}$ Artevelde University of Applied Sciences, Ghent, Belgium

${ }^{3}$ Cabinet Huljev \& Joué, Namur, Belgium

${ }^{4}$ Diagdent, Warszawa, Poland 
5 PANORAMIK Centrum Diagnostyczne w Warszawie, ul. Świętokrzyska 18, Warszawa, Poland

${ }^{6}$ Private dental practice, Langemark, Belgium

7 Oral and maxillofacial surgery research Lab (OMFS Lab), NMSK, Institut de recherche expérimentale et clinique (IREC), UCLouvain, Brussels, Belgium

Corresponding author: Pr R. Olszewski, Department of Oral and maxillofacial surgery, Cliniques universitaires saint Luc, OMFS LAB, NMSK, IREC,

UCLouvain, Brussels, Belgium, phone+3227645718; fax: +3227645876; ORCID iD:orcid.org/0000-0002-2211-7731

Disclaimer: the views expressed in the submitted article are our own and not an official position of the institution or funder. 
Stafne bone cavity (SBC) is a rare entity to find on panoramic radiography and on cone beam computed tomography. We reviewed in a systematic way the openaccess literature from PubMed and DOAJ. We also proposed a new methodology consisting of collaboration with private practitioners, application of participative science approach, and open science practices, and using social media tool to obtain and describe seven different cases of SBC. We finally propose a new matrix table for classification of anatomical types of SBC already described and those yet to be described in open-access litera ture.

Keywords: stafne defect, stafne bone cavity, CBCT, open-access, a natomical variation 


\section{Introduction}

Stafne bone cavity (SBC) or Stafne bone defect [1] represents a non-frequent anatomicalfinding, which can be found on mandibular cone beam computed tomography (CBCT), and panora mic radiographs. Correct identification of the "lesion" is essential as it does not require any treatment. Incorrect diagnosis may lead to unnecessary additional radiographic assessment and/or surgical procedures [2].

Stafne bone cavity (SBC) was first described by Stafne [1] in 1942. He reported 35 asymptomatic and unilocular radiolucencies located in the posterior region of the mandible, between the mandibular angle and the third molar, slightly above the mandibularbase and inferior to the mandibular canal [1]. Some a uthors consider this entity as a pseudocyst in the absence of a real cavity in mandibularbone with no epithelial lining found histologically [3]. Anatomically, SBC looks like a welldefined defect appearing round or ovoid on the lingual side of the mandible [4-8]. To describe this entity, many other names have been given including lingual mandibular bone depression, sta tic bone cyst, Stafne bone cavity (SBC), aberra nt or ectopic salivary gland, static/latent or idiopathic defect, mandibular salivary gland inclusion, lingual mandibular bone depression [5,9]. Nowadays, pathogenesis is still unclear and may explain etymological difficulties $[4,5,10]$. Stafne suggested that the cavity could be the result of a failure of ossification in an area initially constituted by cartilaginous tissue, and be considered as congenital defect due to a defect in osteogenesis [1]. However, the most widely accepted hypothesis is that these cavities develop as a result of a localized pressure atrophy of the lingual surface of the mandible from the adjacent salivary gland (involving submandibular, sublingual or parotid gland) [3,9]. Sublingual glands are supposed to be related to anterior type of SBC which is situated above the insertion of mylohyoid muscle [3, 8]. Submandibular glands are related to the posterior type of SBC [3, 8], and parotid gland may be responsible of SBC in the ascending ramus of the mandible [3]. This hypothesis is based on findings reported after surgical exploration and on CT analysis of soft-tissue images [11]. Fat tissue, lymph nodes, vessels, and vascular lesions [9], conjunctive tissues could be also found in SBC [9, 11].

SBC are mostly observed in male patients with a predominance of patients diagnosed between 40 and 70 years-old [6-8]. In a retrospective study performed by Sisman and al. [9] on 34.221 patients, a prevalence of $0.08 \%$ has been found with a preferential localization in the lingual molar area $[6,8,9]$. In addition to this most frequently described posterior type, we may also notice the onset of SBC in the premolar region above the insertion of mylohyoid muscle (anterior type), and in the ascending ramus of the mandible (mandibular ramus type) [4, 8].

The differential diagnosis of SBC involves odontogenic cystic lesions, ameloblastoma, fibrous dysplasia, vascular malformations, giant cell granuloma, odontogenic kera tocyst, a neurysmalbone cyst, eosinophilic granuloma, benign salivary gland tumours, neurogenic tumours, myxoma, multiple myeloma, and metastatic diseases [6].

In general, SBC are found incidentally on routine panoramic radiography in 
patients who usually do not present clinical symptoms $[4,5,7,10,11]$. The cortical outline of the bone appears thicker than that of odontogenic cysts [5]. The lesion is distributed evenly on both mandibular sides, with a mean supra-centimetric size [4, 5]. The most common presentation is unilocular even if multilocular, double unilocular, bilocular or bilateral localization can also occur [4-6, 8, 10]. SBC was shown to be an anatomical rather than a pathologicalcondition, therefore it does not require any therapeutic or surgical treatment $[7,8]$. A radiological follow-up is usually performed to ensure the static aspect of the lesion throughout time, and scarcely surgical exploration or biopsy were performed when the diagnosis was uncertain or the case was atypical [4, 5]. The CBCT and MRI [6-8] or CBCT and sialography $[6,8]$ were also proposed to help in diagnosis in some doubtful cases [6].

The aim of this review was to assess the medical literature based only on open access articles related to this topic, using only two databases, Pubmed and Directory of Open access journals (DOAJ), while working from home, in order to mimic the same situation as a private practitioner would be searching for contributive information and for CBCT reference images on SBC [12, 13]. Our aim was also to describe seven different SBC cases from our University clinics and from private practitioners, and to propose a matrix table for classification of SBC anatomical types already described and those yet to be described.

\section{Material and methods}

Only free full-text articles published about CBCT being used for SBC diagnosis were included in the PubMed search. Articles about SBC without the use of CBCT, and articles without open-access were excluded. Searches were carried out for articles in English and in French, and performed by only one author on 22.02.2021.

The search equation on PubMed was performed in three steps: 1,stafne,,"'"'stafne"'"[All Fields] OR "'"stafne s"'"[All Fields]",263,14:01:56 2,stafne,,Free full text,"("'stafne"'"[All Fields] OR "'stafne s"'"[All Fields]) AND (ffrft[Filter])",64,14:02:02

3,stafne CBCT,,Free full text,"(("'stafne"'"[All Fields] OR "'stafne s"'[All Fields]) AND "'CBCT"'[All Fields]) AND (ffrft[Filter])",6,14:02:22

Six articles corresponded to our inclusion and exclusion criteria [3-5, 9, 11 13].

For DOAJ the words "stafne" and "CBCT" were selected which resulted in 5 articles, using the same inclusion and exclusion criteria as for PubMed database. The same author performed the search on 23.04.2021. This resulted in an additional5 articles that could be included in the review [6-8, 10, 14]. Subsequently, 11 articles were included in the final review on SBC and CBCT. 
As only 2 cases of SBC on CBCT were found from our University clinic database, a call was made to increase the number of clinical cases, by using social media channels (Nemesis group Facebook webpage https://www.facebook.com/groups/562474671044861). This group is opened mainly to dentists from private practice who are interested in publications in Nemesis journal(https://ojs.uclouvain.be/index.php/nemesis/issue/archive). Five more clinical cases were received as a reply to the call [13].

\section{Clinical cases description}

Patient $n^{\circ} 1$ (male, 49 years-old): unilocular posterior type on the left side of the mandible (Figure 1). The dimensions of the SBC were: mesiodistal $9.3 \mathrm{~mm}$, buccolingual $4.8 \mathrm{~mm}$, and cranio-caudal $10.6 \mathrm{~mm}$. The total volume was $473.18 \mathrm{~mm}^{3}$.

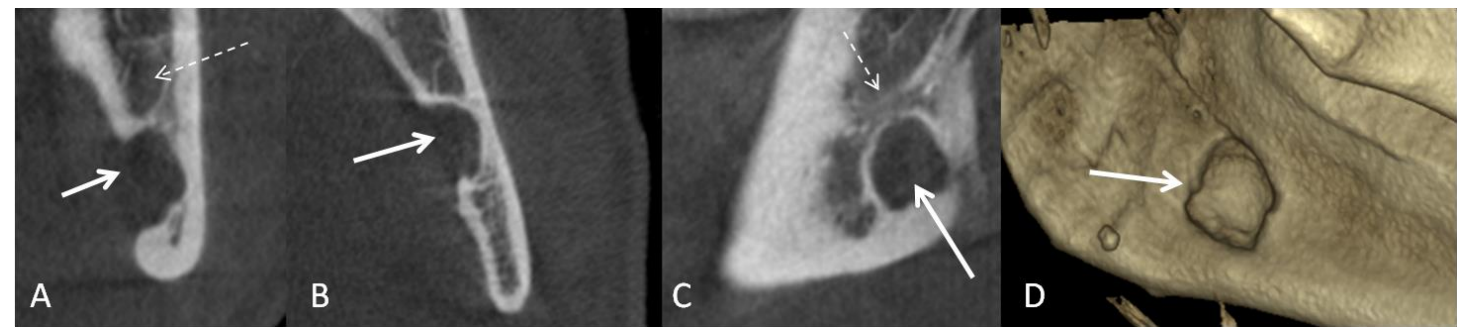

Fig. 1. 2D CBCT reconstruction of a SBC on the left-hand side of the mandible. Fat arrow is showing the SBC and the thin dashed arrow indicates the inf erior alveolar nerve. A. Coronal view. B. Axial view. C. Sagittal view. 3D reconstruction.

Patient $\mathrm{n}^{\circ} 2$ (female, 82 years-old): unilocular ascending ramus type on the right lingual side of the mandible (Figures 2,3). The dimensions of the SBC were: mesiodistal $4.8 \mathrm{~mm}$, buccolingual $1.6 \mathrm{~mm}$, and cranio-caudal $3.9 \mathrm{~mm}$. The total volume was $29.95 \mathrm{~mm}^{3}$.

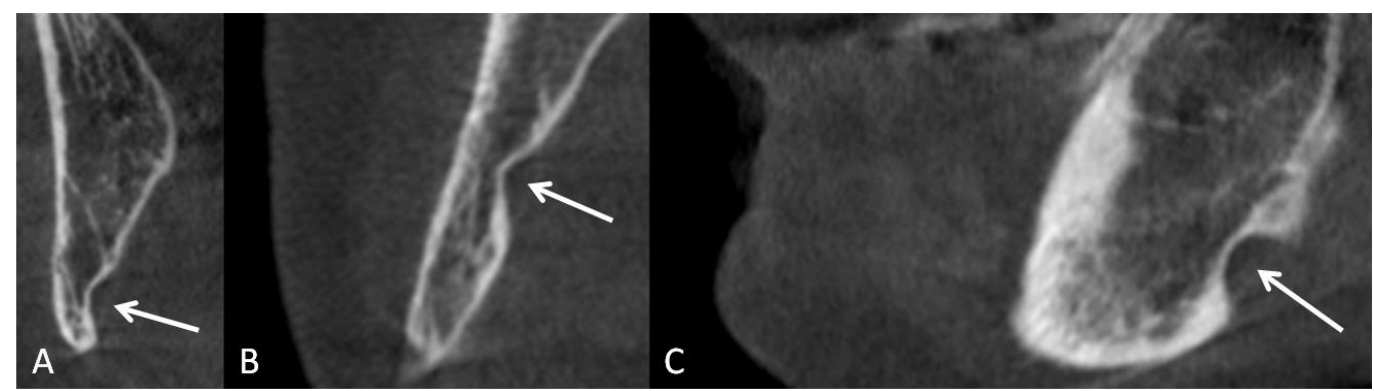

Fig. 2. 2D CBCT reconstruction of a SBC (fat arrows) on the right-hand side of the mandible. A. Coronal view. B. Axial view. C. Sagittal view. 


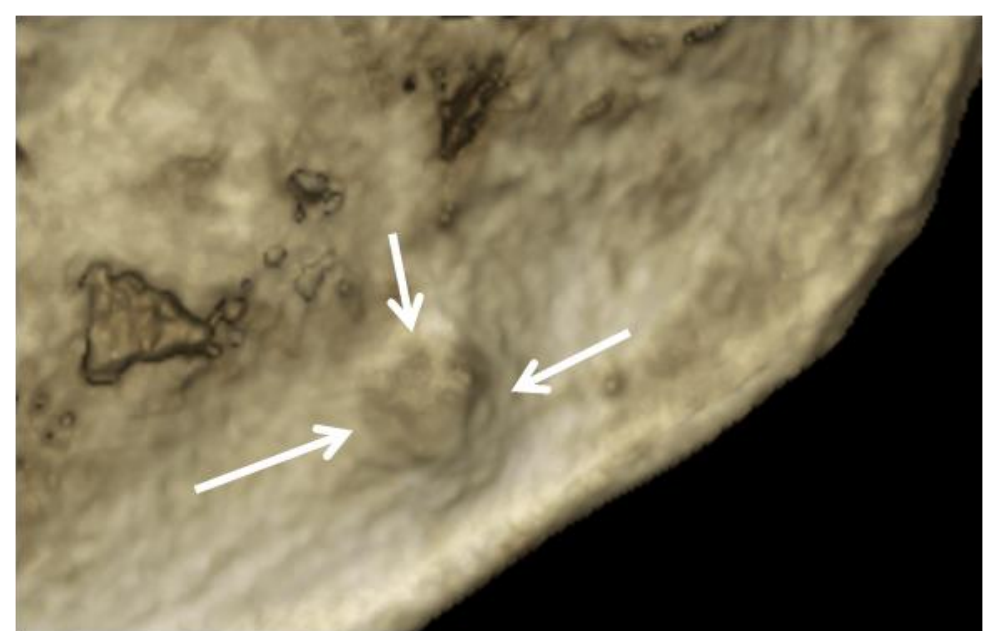

\section{Fig. 3. 3D CBCT reconstruction of the SBC shown in figure 2.}

Patient $n^{\circ} 3$ (male, 64 years-old): bilocular posterior type on the right lingual side of the mandible (Figures 4,5). The dimensions of the SBC were: mesiodistal $15.8 \mathrm{~mm}$, buccolingual $3.8 \mathrm{~mm}$, and cranio-caudal $8.6 \mathrm{~mm}$. The total volume was $516.3 \mathrm{~mm}^{3}$.

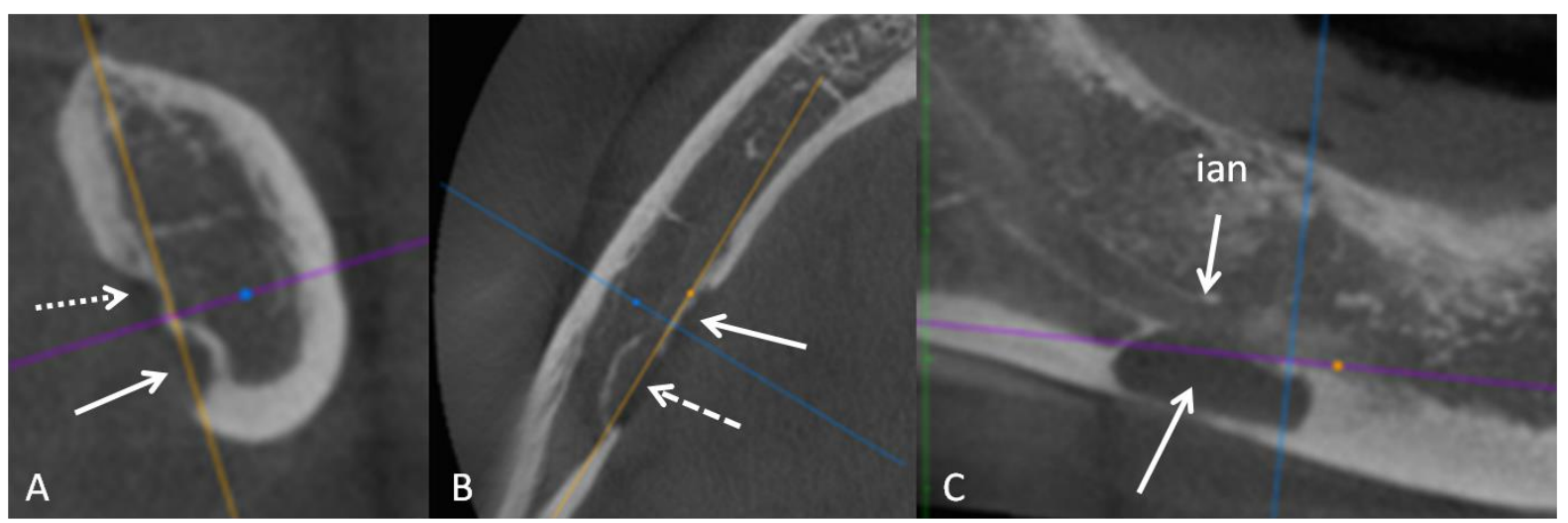

Fig. 4. 2D CBCT reconstruction of a bilocular SBC (fat arrows) on the right-hand side of the mandible. A. Coronal view: Arrow: lower compartment of the SBC. Dotted arrow: upper compartment of the SBC. B. Axial view: Arrow: anterior compartment of the SBC. Dashed arrow: posterior compartment of the SBC. C. Sagittal view. Arrow: SBC. ian: inferior alveolar nerve canal. 


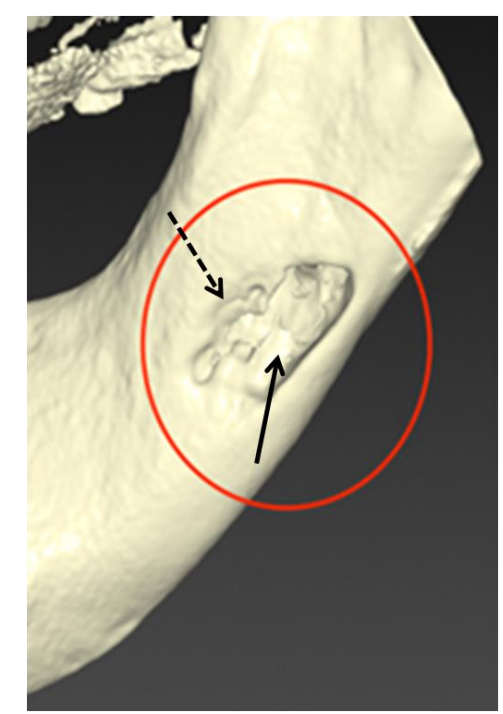

Fig. 5. 3D CBCT reconstruction of the bilocular SBC shown in figure 4. Arrow: lower compartment of the SBC. Dashed arrow: upper compartment of the SBC.

Patient $\mathrm{n}^{\circ} 4$ (male, 55 years-old): unilocular posterior type on the right lingual side of the mandible (Figures 6,7). The dimensions of the SBC were: mesiodistal $10.2 \mathrm{~mm}$, buccolingual $4.6 \mathrm{~mm}$, and cranio-caudal $6.4 \mathrm{~mm}$. The total volume was $300.28 \mathrm{~mm}^{3}$.

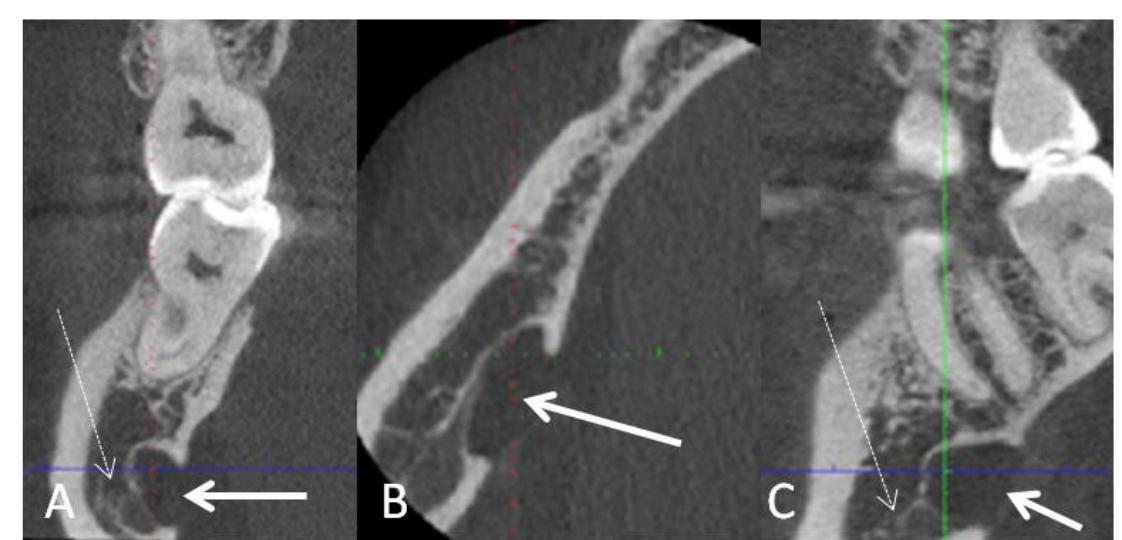

Fig. 6. 2D CBCT reconstruction of a unilocular posterior SBC (fat arrows) on the right-hand side of the mandible. Fat arrow is showing the $\mathrm{SBC}$ and the thin dashed arrow indicates the inferior alveolar nerve. A. Coronal view. B. Axial view. C. Sagittal view. 


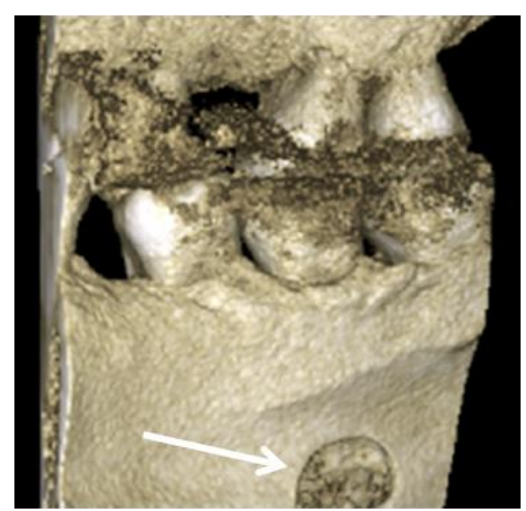

Fig. 7. 3D CBCT reconstruction of a unilocular posterior SBC shown in figure 6 (cropped image).

Patient $\mathrm{n}^{\circ 5}$ (male, 61 years-old) unilocular lateral type on the right lingual side of the mandible (Figures 8-10).

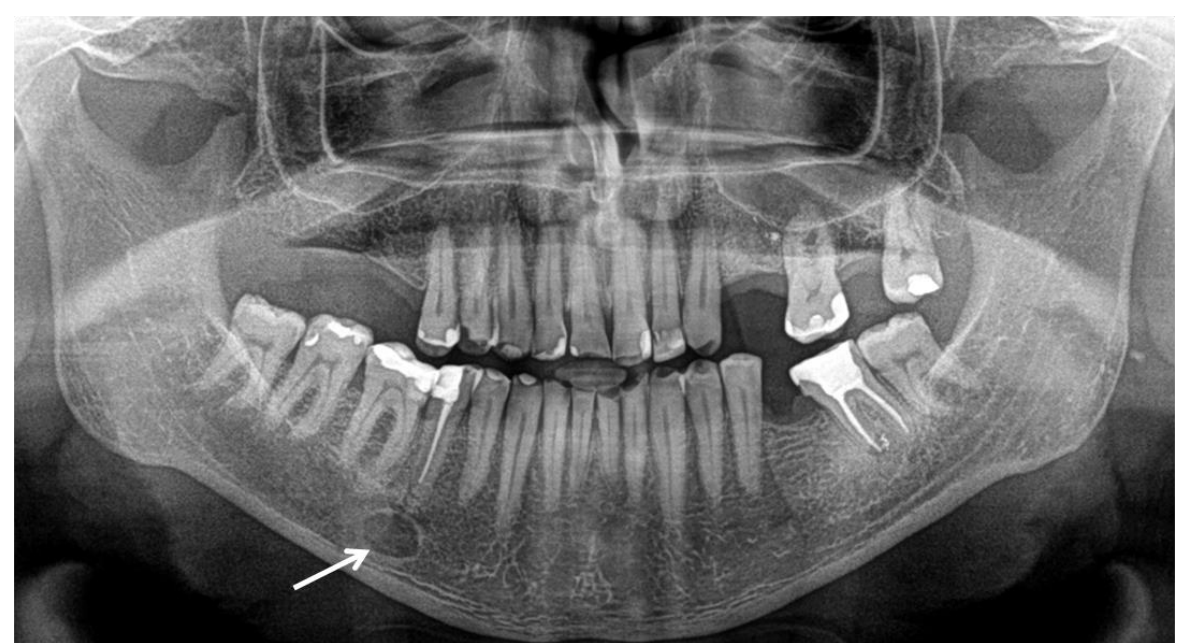

Fig. 8. Panoramic radiography. Arrow: possible diagnosis of SBC on the right side of the mandible. 


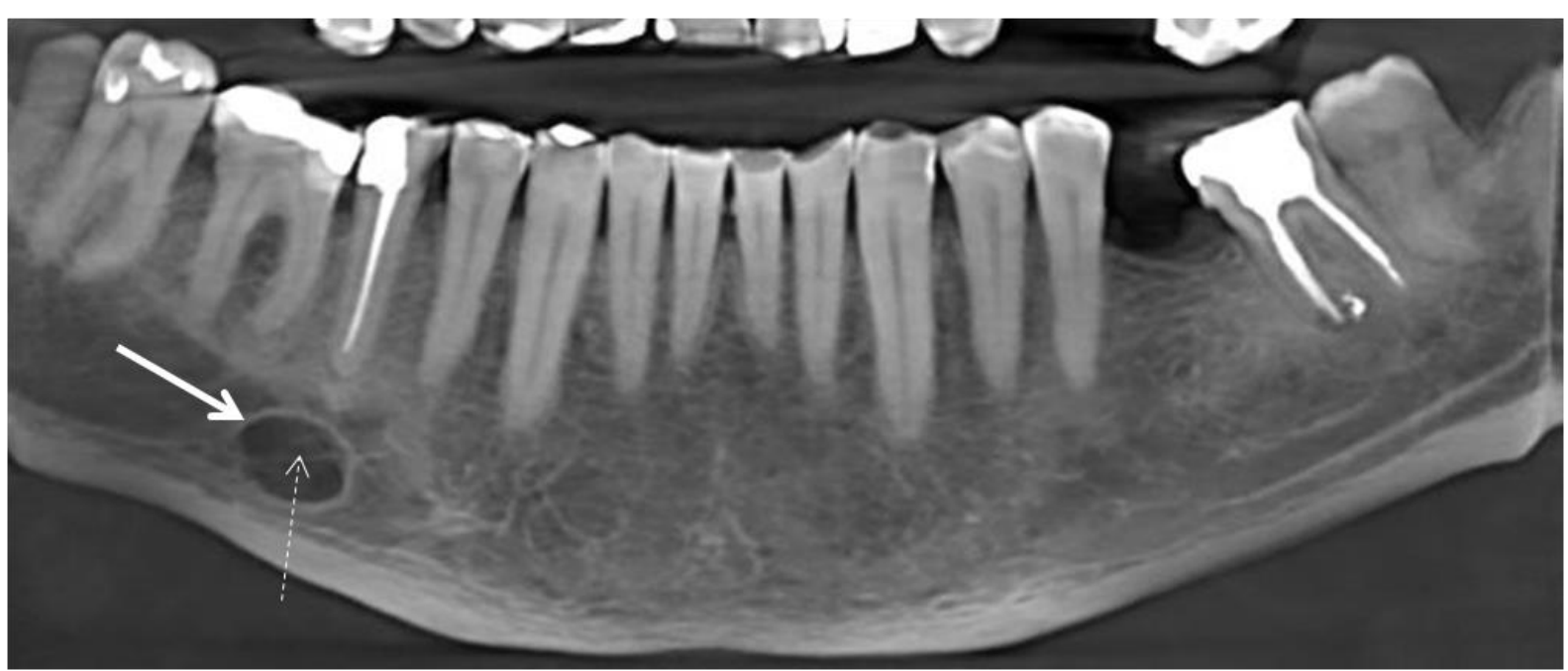

Fig. 9. 2D CBCT pseudopanoramic reconstruction. Arrow: well defined cavity apical to teeth roots. Dashed thin arrow: inf erior edge of the right inf erior alveolar nerve canal is superimposed on the image of the cavity.

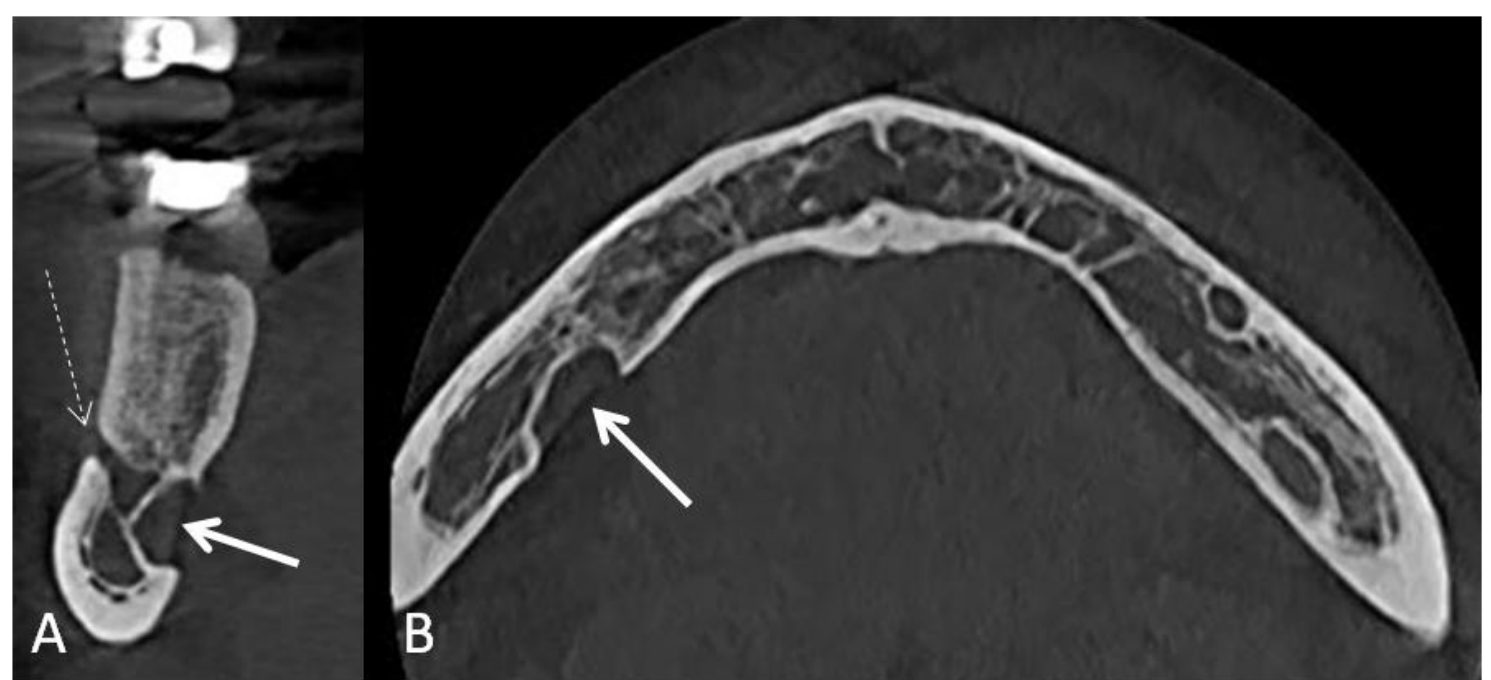

Fig. 10. 2D CBCT reconstruction of a unilocular lateral SBC (fat arrows) on the right-hand side of the mandible. A. Coronal view. Thin arrow: right mental foramen. B. Axial view. 
Patient ${ }^{\circ} 6$ (male, 53 years-old) unilocular, mandibular angle $\mathrm{SBC}$ on the right lingual side of the mandible (Figures 11, 12). The dimensions of the SBC were: mesiodistal $10.1 \mathrm{~mm}$, and the buccolingual length of $7.7 \mathrm{~mm}$.

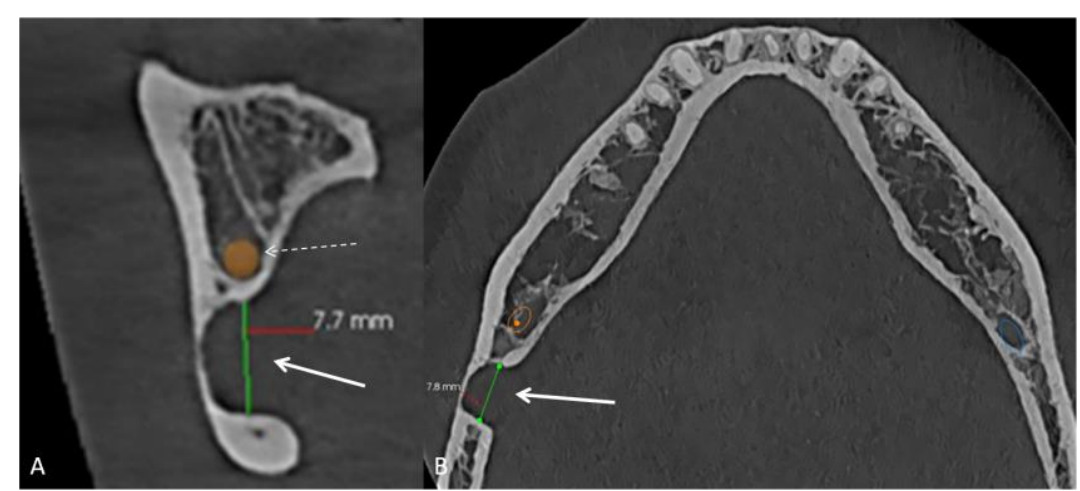

Fig. 11. 2D CBCT reconstruction of deep, unilocular, mandibular angle SBC (fat arrows) on the right-hand side of the mandible. A. Coronal view. Thin dashed arrow: right inferior alveolar nerve canal. B. Axial view.

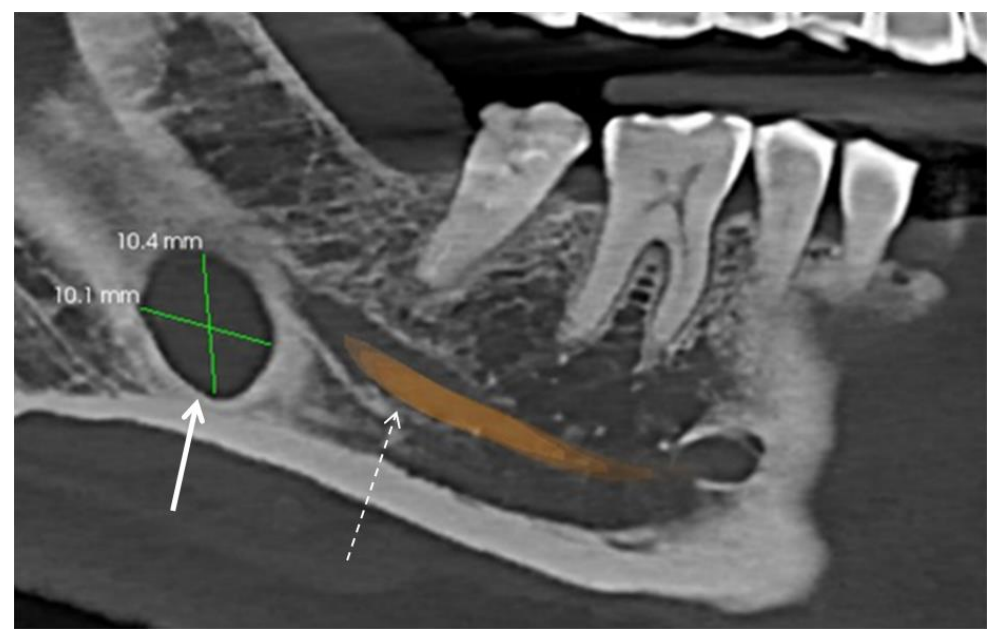

Fig. 12. 2D multi-reformatted sagittal reconstruction. Arrow: ovoid SBC in the area posterior to the dental arch; and below the inferior alveolar nerve canal (thin dashed arrow). 
Patient $\mathrm{n}^{\circ} 7$ (male, 43 years-old) unilocular lateral SBC on the left lingual side of the mandible (Figures 13-17). The dimensions of the SBC were: mesiodistal $13.2 \mathrm{~mm}$, buccolingual $8.4 \mathrm{~mm}$, and cranio-caudal $12.8 \mathrm{~mm}$. The total volume was $1419.26 \mathrm{~mm}^{3}$.

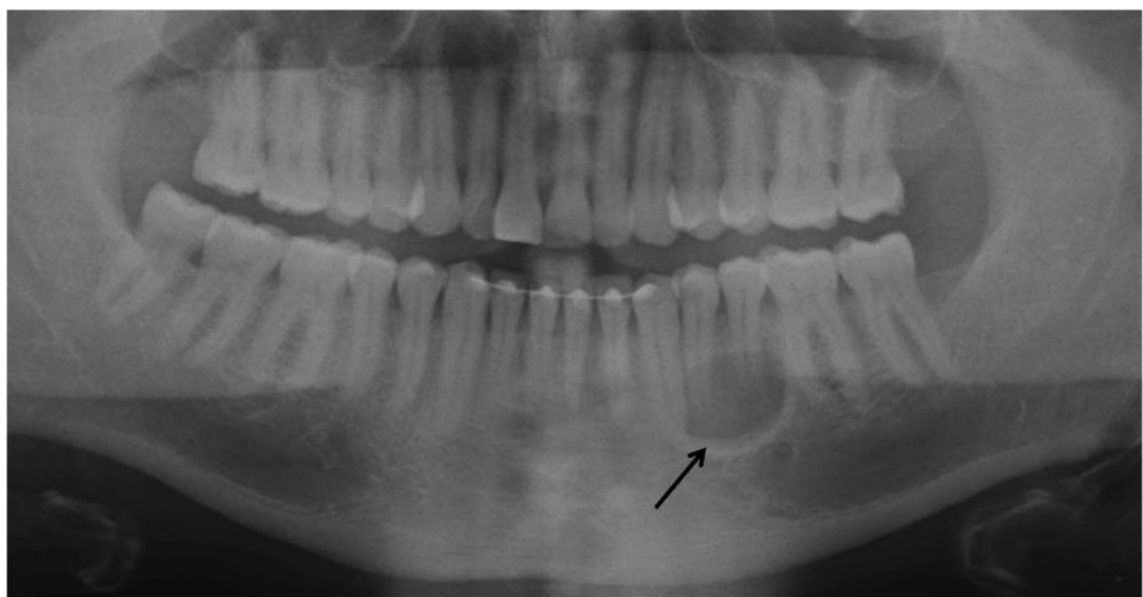

Fig. 13. Panoramic radiography. Arrow: Unilocular radiolucency around the roots of teeth 34 and 35 .

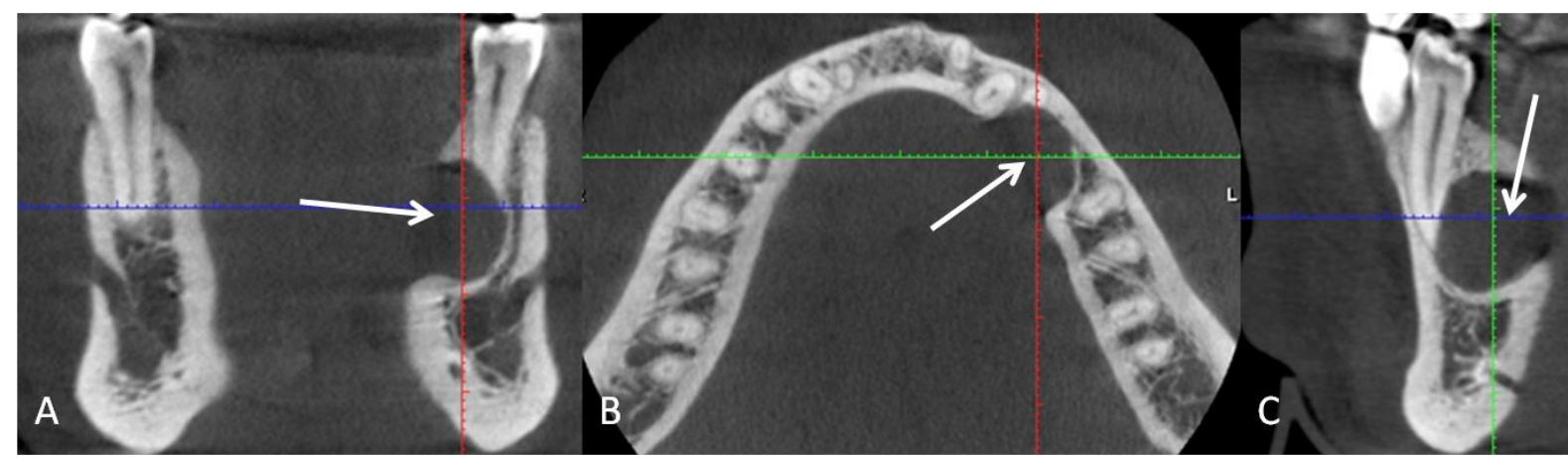

Fig. 14. 2D CBCT reconstruction of unilocular lateral SBC on the lefthand side of the mandible (fat arrows). A. Coronal view. Shape modification of the apex of the tooth 35 (vital) in relation with SBC. B. Axial view. C. Sagittal view. No shape modification of the apex of tooth 34 (vital). 


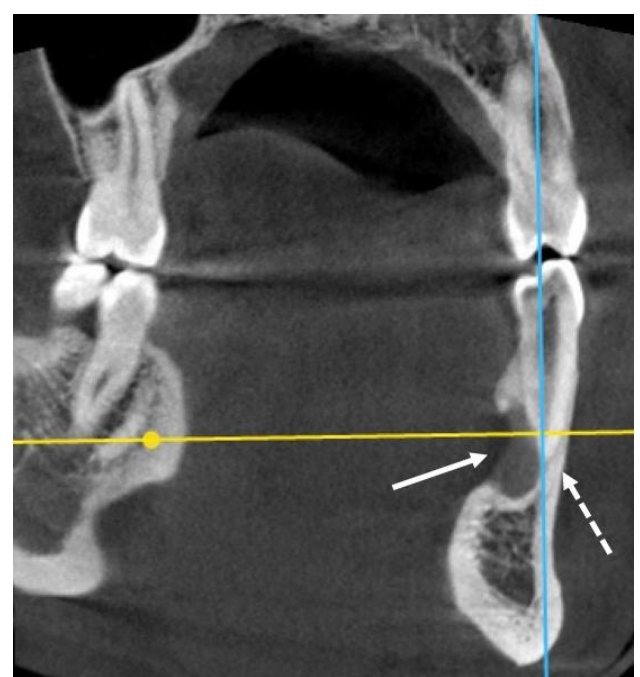

Fig. 15. 2D CBCT reconstruction of unilocular lateral SBC on the lefthand side of the mandible (fat arrow). Coronal view. Dashed arrow: intact apex of tooth 34 (tooth vital without decay).

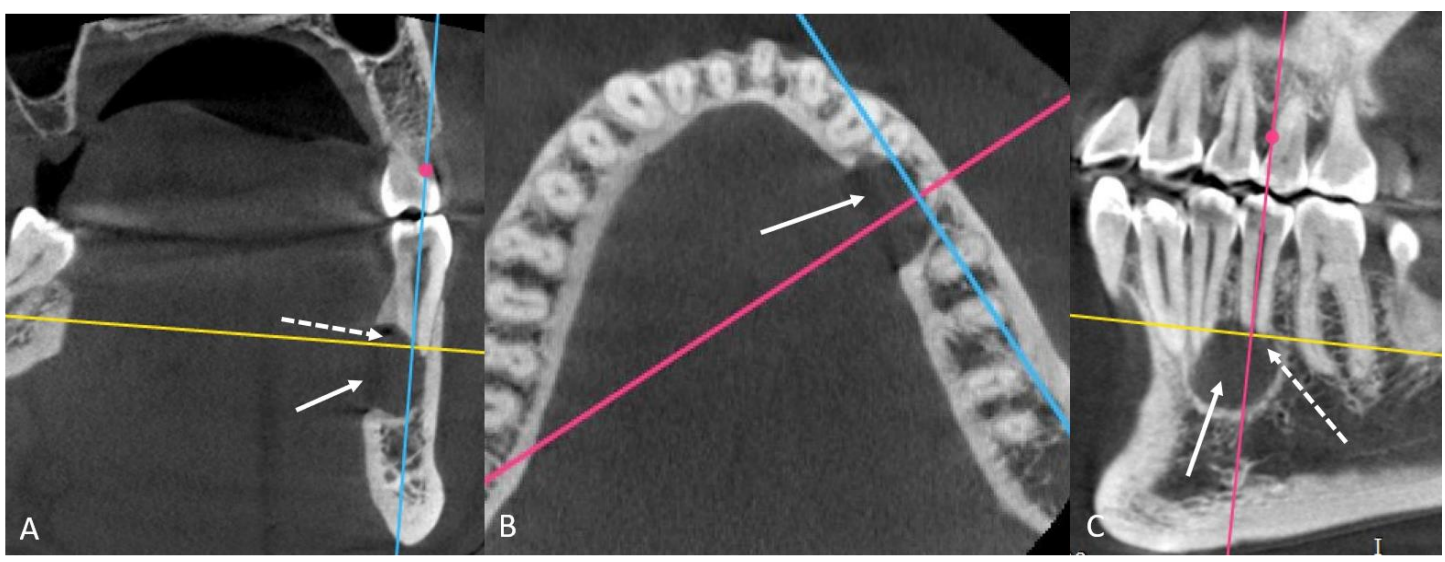

Fig. 16. 2D CBCT reconstruction of unilocular lateral SBC on the lefthand side of the mandible (fat arrow). A. Coronal view. Dotted arrow: modified shape of the apex of the tooth 35. B. Axial view. C. Sagittal view. Dashed arrow: modified shape of the apex of tooth 35 in relation with the SBC. 


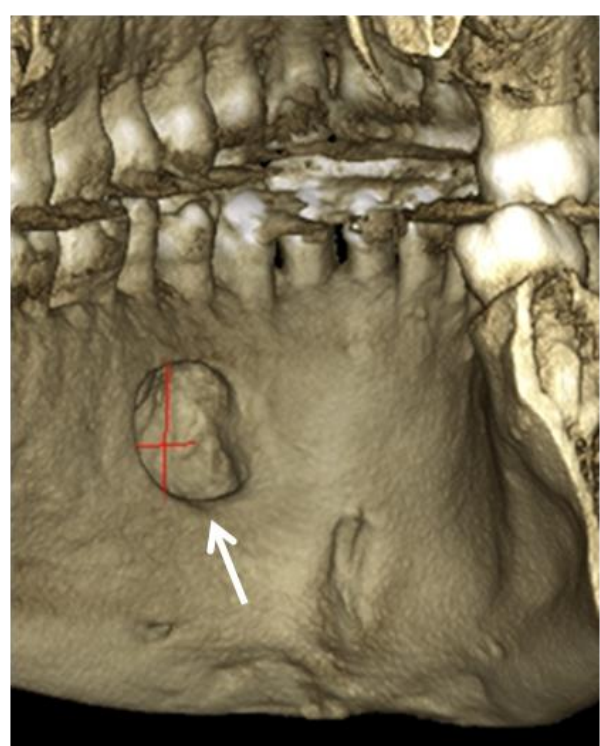

Fig. 17. 3D CBCT reconstruction of the unilocular SBC shown in figures 14-16.

\section{Discussion}

$\mathrm{SBC}$ is a rare entity to find on panoramic radiography and on CBCT $[8,9,12]$. Vaezi et al. found $10 \mathrm{SBC}$ from $5000 \mathrm{CBCT}$ and their article contains only 2 clinic 1 illustrated cases of SBC on CBCT [8]. Sisman et al. reviewed panoramic radiographs from 34,221 patients, and found only $6 \mathrm{SBC}$ with their article providing with only one case of SCB on CBCT [9]. Adisen reviewed panoramic radiographs from 16,782 patients, and found 14 cases of SBC [14]. However, Adisen et al., [14] shows only 3D CBCT reconstruction of three types of SBC in relation with the inferior alveolar nerve, and without any other clinical illustration [14].

Our case series resulted from new methodology consisting of collaboration with private practitioners, application of participative science approach and open science practices. Sharing and collaborating from the early stages of the resea rch is essential for open science. This is why the invitation to participate and share images was posted on Nemesis Facebook group, and not through traditional academic channels. This call to manifest the interest allows reaching dentists from private practice, who shared their unique SBC cases with us. We were able to harvest in a very short time an important additional set of seven SBC cases.

In our series, the patient age ranged from 43 to 82 years-old with a mean age of 58 years-old. It corresponds to the range from 40 to 70 years-old already reported in the open-access literature [6-8]. Our sample consisted of $85.7 \%$ male patients, which is 
almost identical to the $85 \%$ mentioned by Sisman and al. [9]. Our volume measurements of 5 SBC ranged between $29.95 \mathrm{~mm}^{3}$ and $1419.26 \mathrm{~mm}^{3}$ (mean: $547.79 \mathrm{~mm}^{3}$ ) which was greater than what the study by Adisen reported (14 SBC ranging between $160 \mathrm{~mm} 3$ and $520 \mathrm{~mm} 3$ (mean: $361.7 \mathrm{~mm}^{3}$ )) [14].

Different types of classifications of SBC were already proposed. Ariji classification of SBC initially based on CT scan, and reported by Unsal et al., [6] and Vaezi et al. [8] describes 3 types of buccolingual extension of the SBC.

Moreover, the latter described SBC by: 1) the shape of SBC: unilocular, bilocular or multilocular shape; 2) the laterality: unilateralor bilateral; and 3) the location: anterior type-below the premolars, and posterior type-below the molars and behind the molars. Adisen et al. proposed a classification based on the relationship with the inferior alveolar nerve (ian) with 3 types: 1) SBC below the ian; 2) SBC above ian; 3) ian going through SBC [14].

Looking at our cases and the cases collected from open-access literature it is possible to add some modifications to these existing classifications. The Type I of Ariji $[6,8]$ with SBC that are not extending to the buccal cortical plate corresponds to a large range of possible concavities of the mandible with the SBC being very superficial, and close to the lingual cortical plate to being much deeper concavities. We, therefore propose to add a superficial type: a superficial concavity close to the lingual cortical plate. For the relationship with the ian we propose to add two other types: 1) SBC lateral to ian, and 2) SBC outside of the ian area. Regarding their location we suggest 5 types of location in relation with the dental arch, and with the mandibular anatomy: 1) anterior: between the canines; 2) lateral: from canines to second premolar, 3 ) posterior: first molar to third molar, 4) mandibular angle, posterior of the third molar, 5) ascending ramus.

A modification of the root shape in close relationship with the SBC was noticed in one case of our series and in one figure from Asgary et al [3]. We suggest therefore to add the relationship between SBC and teeth roots as part of classification (Table $1)$.

Reported clinical cases of SBC do not systematically use classifications described above. Moreover, anatomical description itself or the use of only one classification at a time such as the relation with ian or the buccolingual extension of the cavity cannot encompass all the existing types or types still to be discovered. Therefore, we propose a matrix table with a proposal of multiple types of classification applied the clinical case of SBC in the same time. One clinical case can belong to different boxes in the matrix table. This table could be further completed. Other authors could add more types in the same classification or add new classification below the existing ones. As in the periodic table of Mendeleyev there were initially some empty boxes waiting to be completed. Analogically we are leaving empty spaces that could be completed and further published in the openaccess. Bilateral cases can show a different presentation on each side, and are to be 
added separately to this matrix table. The content of present matrix table is based only on descriptions of SBC in open-access literature, and from authors' interpretation of figures and illustrations in open-access selected articles.

Table 1. Matrix table for classification of SBC on CBCT.

\begin{tabular}{|c|c|c|c|c|c|}
\hline & 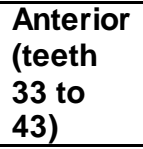 & $\begin{array}{l}\text { Lateral } \\
\text { (teeth } 33 \text { to } \\
35 \text { and/or } \\
43 \text { to } 45 \text { ) } \\
\end{array}$ & $\begin{array}{l}\text { Posterior } \\
\text { (teeth } 36 \text { to } \\
38 \text { and/or } 46 \\
\text { to } 48 \text { ) }\end{array}$ & $\begin{array}{l}\text { Mandibular } \\
\text { angle }\end{array}$ & $\begin{array}{l}\text { Ascending } \\
\text { ramus }\end{array}$ \\
\hline \multicolumn{6}{|l|}{ Shape } \\
\hline Unilocular & $\begin{array}{l}\text { 1 case, } \\
{[15]}\end{array}$ & $\begin{array}{l}1 \text { case }[3], \\
\text { patient } n^{\circ} 5, \\
\text { patient } n^{\circ} 7\end{array}$ & $\begin{array}{l}1 \text { case [5], } \\
1 \text { case [8], } \\
\text { case } n^{\circ} 1[4], \\
\text { case } n^{\circ} 2[4] \\
\text { patient } n^{\circ} 1, \\
\text { patient } n^{\circ} 4\end{array}$ & $\begin{array}{l}1 \text { case [5], } \\
1 \text { case [7], } \\
\text { patient } n^{\circ} 6\end{array}$ & patient ${ }^{\circ} 2$ \\
\hline Bilocular & & & $\begin{array}{l}1 \text { case }[10], \\
\text { patient } n^{\circ} 3\end{array}$ & & \\
\hline Multilocular & & & $\begin{array}{l}1 \text { case }[6], \\
1 \text { case }[11]\end{array}$ & 1 case $[8]$ & \\
\hline \multicolumn{6}{|l|}{ Laterality } \\
\hline Unilateral & $\begin{array}{l}1 \text { case } \\
{[15]}\end{array}$ & $\begin{array}{l}1 \text { case }[3], \\
\text { patient } n^{\circ} 5, \\
\text { patient } n^{\circ} 7,\end{array}$ & $\begin{array}{l}1 \text { case [6], } \\
1 \text { case [5], } \\
1 \text { case [8], } \\
1 \text { case [10], } \\
1 \text { case [11], } \\
\text { case } n^{\circ} 1 \text { [4], } \\
\text { case } n^{\circ} 2[4], \\
\text { patient } n^{\circ} 1, \\
\text { patient } n^{\circ} 3, \\
\text { patient } n^{\circ} 4\end{array}$ & $\begin{array}{l}1 \text { case [5], } \\
1 \text { case [7], } \\
1 \text { case [9], } \\
\text { patient } n^{\circ} 6\end{array}$ & patient $n^{\circ} 2$ \\
\hline \multicolumn{6}{|l|}{ Bilateral } \\
\hline \multicolumn{6}{|l|}{$\begin{array}{l}\text { Depth } \\
\text { (adapted } \\
\text { from Airiji [6, } \\
\text { 8]) }\end{array}$} \\
\hline $\begin{array}{l}\text { Type } 1 \\
\text { superficial }\end{array}$ & $\begin{array}{l}1 \text { case } \\
{[15]}\end{array}$ & & & & patient $n^{\circ} 2$ \\
\hline $\begin{array}{l}\text { Type 2: not } \\
\text { extend to } \\
\text { buccal } \\
\text { cortical plate } \\
\text { (Type I of } \\
\text { Airiji) }[6,8] \\
\end{array}$ & & $\begin{array}{l}1 \text { case }[3], \\
\text { patient } n^{\circ} 5, \\
\text { patient } n^{\circ} 7,\end{array}$ & $\begin{array}{l}1 \text { case [8], } \\
\text { case } n^{\circ} 1[4], \\
\text { case } n^{\circ} 2[4], \\
\text { patient } n^{\circ} 1, \\
\text { patient } n^{\circ} 3, \\
\text { patient } n^{\circ} 4\end{array}$ & 1 case $[9]$ & \\
\hline $\begin{array}{l}\text { Type 3: } \\
\text { extend to } \\
\text { buccal } \\
\text { cortical plate } \\
\text { (Type II of }\end{array}$ & & & $\begin{array}{l}1 \text { case [5], } \\
1 \text { case }[10]\end{array}$ & $\begin{array}{l}1 \text { case [5], } \\
1 \text { case [7], } \\
\text { patient } n^{\circ} 6\end{array}$ & \\
\hline
\end{tabular}




\begin{tabular}{|c|c|c|c|c|c|}
\hline Airiji) $[6,8]$ & & & & & \\
\hline $\begin{array}{l}\text { Type 4: } \\
\text { extend } \\
\text { beyond } \\
\text { buccal } \\
\text { cortical plate } \\
\text { (Type III of } \\
\text { Airiji) }[6,8]\end{array}$ & & & $\begin{array}{l}1 \text { case }[6], \\
1 \text { case }[11]\end{array}$ & & \\
\hline \multicolumn{6}{|l|}{$\begin{array}{l}\text { Relationship } \\
\text { with IAN } \\
\text { (modified } \\
\text { from Adisen } \\
\text { et al, [14]) }\end{array}$} \\
\hline $\begin{array}{l}\text { Type 1: SBC } \\
\text { below ian [14] }\end{array}$ & & & $\begin{array}{l}1 \text { case }[6], \\
1 \text { case }[8], \\
\text { case } n^{\circ} 1[4], \\
\text { patient } n^{\circ} 1, \\
\text { patient } n^{\circ} 3\end{array}$ & $\begin{array}{l}1 \text { case [5], } \\
1 \text { case [7], } \\
1 \text { case [9], } \\
\text { patient } n^{\circ} 6\end{array}$ & \\
\hline $\begin{array}{l}\text { Type 2: SBC } \\
\text { lateral to ian }\end{array}$ & & $\begin{array}{l}1 \text { case [3], } \\
\text { patient } n^{\circ} 5\end{array}$ & patient $n^{\circ} 4$ & & \\
\hline $\begin{array}{l}\text { Type 3: SBC } \\
\text { above ian } \\
{[14]}\end{array}$ & & patient $n^{\circ} 7$ & & & \\
\hline $\begin{array}{l}\text { Type 4: SBC } \\
\text { above and } \\
\text { below ian }\end{array}$ & & & 1 case $[10]$ & & \\
\hline $\begin{array}{l}\text { Type 5: ian } \\
\text { inside SBC } \\
{[14]}\end{array}$ & & & $\begin{array}{l}1 \text { case }[5], \\
1 \text { case }[11], \\
\text { case } n^{\circ} 2[4]\end{array}$ & & \\
\hline $\begin{array}{l}\text { Type } 6: \text { SBC } \\
\text { outside ian } \\
\text { area }\end{array}$ & $\begin{array}{l}1 \text { case } \\
{[15]}\end{array}$ & & & & patient $n^{\circ} 2$ \\
\hline \multicolumn{6}{|l|}{$\begin{array}{l}\text { Relationship } \\
\text { with dental } \\
\text { roots }\end{array}$} \\
\hline $\begin{array}{l}\text { No } \\
\text { involvement }\end{array}$ & $\begin{array}{l}\text { case } \\
{[15]}\end{array}$ & patient $n^{\circ} 5$ & $\begin{array}{l}\text { case } n^{\circ} 1[4], \\
\text { case } n^{\circ} 2[4], \\
1 \text { case [5], } \\
1 \text { case [6], } \\
1 \text { case [8], } \\
1 \text { case [10], } \\
1 \text { case [11], } \\
\text { patient } n^{\circ} 1, \\
\text { patient } n^{\circ} 3, \\
\text { patient } n^{\circ} 4\end{array}$ & $\begin{array}{l}1 \text { case [5], } \\
1 \text { case [7], } \\
1 \text { case [9], } \\
\text { patient } n^{\circ} 6\end{array}$ & patient $n^{\circ} 2$ \\
\hline $\begin{array}{l}\text { Root(s) } \\
\text { shape } \\
\text { modification } \\
\text { (tooth vital) }\end{array}$ & & $\begin{array}{l}1 \text { case [3], } \\
\text { patient } n^{\circ} 7\end{array}$ & & & \\
\hline
\end{tabular}


Looking at Table 1, the anterior and the ascending ramus locations are the most unusuallocation presentations. Bilocular and multilocular cases are rare and it appears that bilateral cases were not yet described in open-access literature. The most frequent description is a posterior, unilateral SBC not extending to the buccal cortical plate, below the ian, and without involvement with teeth roots (Table 1).

This article could be re-published in versioning if more cases are transmitted. The aim is to share annotated images in the open-access way, allowing all dentists to have access to the scientific literature not hidden behind paywalls. Scientific publications can origin from the priv ate practice and universities open collaboration . This is a way of using collective intelligence and a wealth of data bases for the profit of the whole community.

- Acknowledgements: none

- Funding sources statement: This study did not receive any funding

- Competing interests: Professor R. Olszewski is Editor-in-Chief of NEMESIS. Professor J. Aps is member of Editorial Board of NEMESIS. All other authors declare no conflicts of interest.

- Ethical approval: We obtained the approval from our University and Hospital Ethical committee for this study (B403/2019/03DEC/542).

- Informed consent: written consent was obtained for the patient $n^{\circ} 3$. Patients $\mathrm{n}^{\circ} 1$ and 2 were exempted from the informed consent according to the ethical committee a pproval. There was no need for informed consent for patients $n^{\circ} 4-7$ as all the images are anonymized, and no private data were provided allowing the patient's identification.

\section{Authors contribution:}

\begin{tabular}{|l|l|}
\hline Author & Contributor role \\
\hline Dive Benoit & $\begin{array}{l}\text { Writing original draft preparation, Writing } \\
\text { review and editing }\end{array}$ \\
\hline Aps Johan & $\begin{array}{l}\text { Data curation, Validation, } \\
\text { Writing review and editing }\end{array}$ \\
\hline Huljev David & $\begin{array}{l}\text { Data curation, Validation, } \\
\text { Writing review and editing }\end{array}$ \\
\hline
\end{tabular}




\begin{tabular}{|l|l|}
\hline Gurniak Anna & $\begin{array}{l}\text { Data curation, Validation, } \\
\text { Writing review and editing }\end{array}$ \\
\hline Klein-Dębek Emilia & $\begin{array}{l}\text { Data curation, Validation, } \\
\text { Writing review and editing }\end{array}$ \\
\hline Beyls Hilde & $\begin{array}{l}\text { Data curation, Validation, } \\
\text { Writing review and editing }\end{array}$ \\
\hline Hebda Aleksandra & $\begin{array}{l}\text { Methodology, Validation, } \\
\text { Writing original draft preparation, Writing } \\
\text { review and editing }\end{array}$ \\
\hline Olszewski Raphael & $\begin{array}{l}\text { Conceptualization, Investigation, } \\
\text { Methodology, Data curation, } \\
\text { Resources, Validation, } \\
\text { Writing original draft preparation, } \\
\text { Supervision, Writing review and editing }\end{array}$ \\
\hline
\end{tabular}

\section{References}

1. Stafne EC. Bone cavities situated near the angle of the mandible. JADA 1942;29:1969-1972.

2. Aps JKM, Koelmeyer N, Yaqub C. Stafne' bone cyst revisited and renamed: the benign mandibular concavity. Dentomaxillofac Radiol2020:49:20190475.

3. Asgary S, EmadiN. Cone-beam computed tomography a nalysis of lingual mandibular bone depression in the premolar region: A case report. Clin Case Rep 2020;8:523-526.

4. Venkatesh E. Stafne bone cavity and cone-beam computed tomography: a report of two cases. J Korean Assoc Oral Maxillofac Surg 2015;41:145-148.

5. Münevveroğlu AP, Aydın KC. Stafne bone defect: report of two cases. Case Rep Dent 2012;2012:654839. 
6. Unsal G, Karapınar G, Ozcan I, Birke Koca R, Olgaç V, Orhan K. Stafne bone cavity with expansion at posterior mandible: A case report and review of the literature. Oral and MaxillofacialSurgery Cases 2020;6:100132.

7. Aydin U, Oguz Y. Stafne bone cavity incidentally 'Twice" diagnosed on panoramic radiographs. J Oral Maxillofac Radiol 2014;2:26-29.

8. Vaezi T, Razmara F, Khajavi A, Hoseini Zarch SH. Radiographic evaluation of Stafne bone cyst in patients referred to a radiology center in Mashhad, Iran: A 3 year survey. J Craniomax Res 2018;5:43-49.

9. Sisman Y, Miloglu O, Sekerci AE, Yilmaz AB, Demirtas O, Tokmak TT.

Radiographic evaluation on prevalence of Stafne bone defect: a study from two centres in Turkey. Dentomaxillofac Radiol2012;41:152-158.

10. Imanimoghaddam M, Darijani M, Keshavarzi M. Bilocular Stafne bone defect above and below the inferior alveolar canal a ssessed by Cone Beam Computed Tomography: A case report. Journal of Dental Materials and Technique 2015;4:127132.

11. Li B, Long X, Cheng Y, Wang S. Cone beam CT sialography of Stafne bone cavity. Dentomaxillofac Radiol. 2011;40:519-523.

12. Olszewski R, Hebda A. Accessibility to the knowledge on anatomical va riations from dentomaxillofacialCBCT. Nemesis 2020;10:1-19.

13. Hebda A, Theys S, de Roissart J, Perez E, Olszewski R. Contribution of dental private practitioners to publications on a natomical variations using cone beam computed tomography. Nemesis 2020;14:1-54.

14. Adisen MZ, Yilmaz S, Misirlioglu M, Atil F. Evaluation of volumetric mea surements on CBCT images using stafne bone cavities as an example. Med Ora 1 Patol Oral Cir Bucal 2015;20:e580-586.

15. Shokri A, Baharvand M, MortazaviH. Is cone-beam computed tomography diagnostic for anterior Stafne bone cyst: Report of a rare case. Dent Hypotheses 2015;6:31-33. 